\title{
Charles Tilly: Connecting Large Scale Social Change and Personal Narrative
}

\author{
by Ernesto Castañeda \\ Columbia University \\ Sociological Research Online 14(5)24 \\ <http://www. socresonline.org.uk/14/5/24.html> \\ doi:10.5153/sro.2036
}

Received:23 Apr 2009 Accepted: 17 Nov 2009 Published: 30 Nov 2009

\begin{abstract}
Charles Tilly's work as a historical sociologist and on states, social change and other topics has had powerful influence across the social sciences and social history, also having a large popular audience. Themes and issues in his work over time are explored, in particular his developing thinking about national states, macro and micro processes, stories and social change.
\end{abstract}

\section{Keywords: Charles Tilly, Contentious Politics, Social Change, Stories, Narratives}

\section{Introduction}

1.1 Charles Tilly, sociologist, incorporated history and politics into his work and has had a large influence on currents in contemporary history and political science in many countries. ${ }^{[1]}$ While the later Tilly was extremely well read and had contact with the best scholars in the world, the earlier Tilly was an autodidact. Tilly began his career writing a thesis on the counterrevolution in a region in rural France. Without having been trained in historical archival research, he went into the archives of a French province to gather data for his dissertation and what later turned into his first and groundbreaking book The Vendée (Tilly, 1964). It is said that he arrived at the archives in Angers and when pressed, demanded in French, Montrez-moi un document!' (Show me a document) (Merriman, 2008). In spite of this naïve beginning, he was able to make history and sociology meet in The Vendée and in the same way, he would later develop very original methods, models, and theories to answer what he saw as important sociological questions. Tilly did archival research incorporating analytical tools that sociologists were using in different areas. This eventually brought him to create catalogs of contentious events, quantitative datasets with strong historical and contextual information that allowed for disciplined comparisons between phenomena such as strikes, protests, social movements, revolts, civil wars and revolutions, across time and space (Tilly, 2008a).

1.2 In 1969 Tilly was invited to form a committee of European historians sponsored by the U.S. Social Science Research Council (SSRC) to test theories of state-making and political development by looking closely at European history. This collective effort produced the influential volume edited by him, The Formation of National States in Western Europe (Tilly, 1975), which contradicted many of the teleological assumptions of the then popular national development and modernization theories (Tilly, 2006b). He pushed for a more historical sociology, with a lengthy methodological exposition in As Sociology Meets History (Tilly, 1981), where he lamented the label of historical sociology understood as a sub-field within sociology rather than a new way to do mainstream sociology (Calhoun and Koller, 2009).

1.3 To celebrate its 75th anniversary, the Russell Sage Foundation asked renowned social scientists to write broadly, and personally, about the current trends in social science. As a result he published Big Structures, Large Processes, Huge Comparisons (Tilly, 1984). This influential book contains a good summary of Tilly's general views on how social science should be done. It is especially interested in the use of history and comparisons as leverage to understand social change in a way that goes beyond the broad and general statements from nineteenth century thinkers. In Big Structures... he was arguing against the influential (even if sometimes forgotten) spontaneous social theorists of the nineteenth century like Herbert Spencer, Ferdinand Tönnies, Auguste Comte and others, but specially Emile Durkheim. While Tilly agreed in many aspects with Karl Marx, Max Weber and Alexis de Tocqueville, he found their theories too general and requiring further empirical testing. Parsons was a more contemporary intellectual enemy whose theories tried to encompass everything happening around an ethereal entity called 'society'. 
'Sociology's greatest victory as an academic discipline brought its greatest defeat as an intellectual enterprise. Persuading others that a distinct realm called "society" and distinct entities called "societies" freed sociologists to justify their studies ... Society was everything else but the state, or everything but the state, the organization of production, and the structure of distribution' (1984:20-21)

For Tilly (as for Weber before, and for most sociologists now), there are no distinctions between the social, the economic and the political. These arenas are all produced by the interaction of social beings and not just by the aggregation of psychological inclinations.

1.5 While Tilly was interested in the lived experience of regular people, he did not have in mind summarizing individual views in the way a survey poll would do to arrive at 'public opinion'. Trying to relate his sociological approach to that of Paul Lazarsfeld (1901-1976), Tilly wrote,
'Certainly the historical record contains few reliable traces of people's inner dialogs, hidden fantasies, suppressed anxieties, or un-stated preferences. But through a wide variety of collective action ordinary people have left a trail of interests, complaints, demands, and aspirations that remains visible to observers who know where to look (...) We now live in a world in which the idea of a defined aggregate set of preferences at a national level, a sort of public opinion, makes a certain amount of sense. It makes enough sense that nowadays we can consider the opinion survey a complement to, or even an alternative to, voting, petitioning, or protesting. However, if we push back into the strange terrain of western Europe and North America before the middle of the nineteenth century, we soon discover another world. In that world, most people did not vote, petition, or take positions on national affairs in anything like the contemporary meanings of those terms. Yet they did act together on their interests, broadcasting their demands, complaints, and aspirations in no uncertain terms' (Tilly, 1983: 462 emphasis mine)

1.6 In his later books Tilly further pushed his preference for studies based on a relational epistemology, arguing that the best way to study society is by looking at relations, transactions, and dynamic interactions. This does not mean that the later Tilly put his comparative historical approach aside, but it does represent a Tilly that had left behind abstract structuralism and simple causal theories, like the special role of war in his theories of the state for which some have criticized him (Gorski 2003 cited in Loveman, 2005). And it is important to remember that he always welcomed critiques and improvements to his models and theories.

1.7 Tilly contributed to the concept of 'state formation', showing how the historical formation of nationstates in western Europe was strongly linked to wars and the accumulation of capital to finance them. European monarchies fought among each other for control of their colonies and global trade routes. The urgency to finance these wars created in the governments of France and England the need to develop systems to unify militias, govern territories, generate wealth, collect taxes and administrate their estates. From the tools that these governments used, today we have censuses, passports, customs, and accounting systems. These processes resulted in the (to a certain point accidental) creation of strong nation-states, with independent economies, and true governance over a certain territory. The theory of state formation reminds us that nation-states did not arise as a product of a linear evolution but from a particular historical and international context.

$1.8 \mathrm{It}$ is a mistake to treat modern countries as independent cases where national governments would appear on their own; one has to take into account what Tilly, following Reinhard Bendix's Kings or People (Bendix, 1978), calls the demonstration effect' (Tilly 1984:91). Once Haiti, the United States and France had undergone revolutions and declared national states with popular sovereignty there is a model for others to emulate. But looking at the present, Tilly discussed the illusory nature of expecting the same types of state-society relations in countries more recently formed that copied the western European model and expected to recreate by decree institutions top-down from one day to another. Imitating laws and promoting top-down reforms rarely translates into a bottom-up reconfiguration. Local knowledge, customs and traditions have to be taken into account to understand the dynamics between the governed and those governing (Scott, 1998). Once he realized how mistaken was the widespread belief that nation-states progress in a linear unidirectional manner from underdeveloped nations to 'modern' developed nations after they overcome certain crisis, Tilly edited a book series called Studies in Social Discontinuity, concerned with 'challenging political developmentalism and modernization theory' (Calhoun and Koller, 2009:334). Debate: Charles Tilly and Switzerland

1.9 Given the actual history of state formation in western Europe, Tilly compares state formation with the criminal activity of the mafia who engage in protection rackets through which they are paid to offer protection from a threat of violence that they themselves create (Gambetta, 1996). Tilly writes,

'I don't insist on the strong word racket and certainly don't claim that the monopolization of coercion and the extraction of various forms of tribute exhaust the activities of governments. Nevertheless, notice how the analogy with racketeering clarifies the actions of governments we regard as illegitimate and the process by which new governments or quasi-governments arise' (Tilly 1994:58-59 original emphasis)

1.10 Tilly shows how, historically, the art of governing consists of large scale coordination among local leaders, militias, powerful economic classes, and even organized crime (Tilly, 1985, 1992). Using this insight one would have been able to predict, for example, the terrible consequences (i.e. the steep increase in violence and destabilization) that an open war on drugs by the Mexican military commanded by President Felipe Calderon would create. Another example here concerns Tilly's comments, just four days 
after 11 September, 2001, in an online reflection, about the escalation of violence that would result from the 'war on terror' (Tilly, 2001).

1.11 In contrast with the literature which perceives democracy as a goal unto itself with a linear evolution, Tilly proposes that democracy is a reversible process and he introduces a new concept into the literature: de-democratization. Explaining how even mature liberal democracies can experience drawbacks and closings in political rights, civil liberties, or in the treatment of immigrants. In Trust and Rule he reminds us that democracy represents one of many possible political regimes, reflecting a system of social, political and economic relationships and, a certain institutionalization of trust networks (Tilly, 2005b). In Democracy (Tilly, 2007a) he writes that disintegration of segregated trust networks (cliques, orders, sects for Durkheim), the decay of patron-client ties, the declining potential of communities to care for their members, the limits on exclusion of people from capital, property, land and rights, and the resulting mobile labor are all implicated in the ability of people to participate in democratic politics (Tilly, 2009: 326). Through his work on trust networks and relational processes he returned to the interests of nineteenth century thinkers in micro-interactions (even if they may appear in personal narratives as psychological moods).

1.12 Tilly's (1984) Big Structures... deals with large processes and social changes through long stretches of time and across geographies; still he chose the title of this book half-jokingly, as a pun, a hyperbole of his own (and this would not be the last time he would do so). Many of his students organized a conference in his honor in Amsterdam in 1995. Knowingly, they made some T-shirts for the occasion with the motto 'Big Structures, Large Processes, Huge Comparisons, Massive Headaches!' on them. In this book, Tilly advocates historical comparative sociology and discusses how to do it by closely looking at the work of people like Barrington Moore, Theda Skocpol, and Stein Rokkan. But the larger challenge that Tilly put to social scientists and to himself was to bring together the evidence from 'history from below' along with theories and systematic studies of socio-political change. Tilly's book only begins to set up this systematic research methodological and meta-theoretical agenda, although it also shows the epistemology he followed through the rest of his career: comparative historical relational sociology. But it lacks a description of the methodological tools to connect the macro and the micro, structure and agency, large and not so large processes. His proposed solution for this came later in the form of his embrace of mechanisms and processes of a short and middle range, as he said regarding a paper he gave at a conference to commemorate the work of Robert Merton, organized by the SSRC at Columbia University in 2007. Tilly agreed that in a way, his work had tried to offer mid-range mechanisms abstracted from large historical comparative studies. Tilly comments,

'I claim that recent revival of interest in mechanistic explanations within the social sciences advances the program Merton was already advocating half a century ago: developing theoretically sophisticated accounts of social processes somewhere between the stratosphere of global abstraction and the underground of thick description. I also claim that the mechanistic middle range opens social science to history much more readily than do competing approaches to explanation of social processes' (Tilly, 2007b; emphasis mine)

1.13 For Tilly the empirical discovery and description of causal mechanisms became the epistemological and methodological way to connect the micro with the macro. With Sydney Tarrow, and Doug McAdam (McAdam et al., 2001), Tilly came up with an approach to social movements and political social action known as 'contentious politics'(Tilly and Tarrow, 2007) based on a set of general processes and mechanisms (see Appendix B).

1.14 In my opinion, some of the best results of this agenda are described in Tilly's Durable Inequality (Tilly, 1998); the list of mechanisms include boundary making, exploitation, opportunity hoarding, emulation and adaptation. Tilly also explains how inequality and exploitation reproduce themselves through the institutionalization of group behaviors and above all through the assignment of professions to certain social categories (Zelizer and Tilly, 2006; Tilly, 2007c). For example in post-colonial societies like Mexico, indigenous people work in the fields, mestizos in the service sector, and whites as senior managers; or in advanced economies like the United States, women work in sales, men in production, immigrants as janitors, and white males as managers. Once these roles and different levels of life become invisible and seem natural, spontaneous or merited, the inequalities between groups reproduce themselves for generations.

1.15 With E.P. Thompson, Eric Hobsbawm, George Rudé and others, Tilly was part of a 'populist social history' rising up in the 1960s (Tarrow, 1987) that wanted to hear about ordinary people and their struggles. The problem with Tilly's work in this middle period is that he only 'listens' to people when they act collectively through known contentious repertoires. Consequently his micro-historical work fails to listen to those without a voice and those who failed to organize and engage in collective action. In contrast, one of his students at the New School, Javier Auyero (2003), based his Contentious Lives: Two Argentine Women, Two Protests, and the Quest for Recognition on narratives and interviews with women protestors. Auyero's aim is to understand the role that protesting played in the lives of these two women afterwards; but it still leaves the problem for Tilly of how to incorporate the voices of those 'really miserable people [who] devote so much of their energy to survival that they have none left to revolt' (Tilly, 1976 [1964]:vii). The methodological challenge is how to listen to the lives, narratives and experiences of ordinary people who ordinarily do not engage in contentious politics, or may not even vote, or be registered in censuses, as is the case of undocumented immigrants.

1.16 One logical step would be to take an ethnographic approach (as he encouraged me to do in my dissertation work, which looks at the political voice and lack thereof amongst new immigrants in different political regimes), yet he never ventured along this road himself. Thus while Tilly was not directly an ethnographer, I would claim that thanks to his many ethnographer colleagues and students, his later work had a great sense of what good ethnography entailed. He commented astutely on ethnographic work itself. For example, after commenting on the many good points raised by anthropologist Jean-Loup Amselle on 
his book Affirmative Exclusion (Amselle, 2003) about the exclusion of ex-colonial subjects in France, Tilly reprimanded him for his top-down approach because in his opinion, despite having done ethnographic work, Amselle over-emphasized intellectual histories and the thoughts of the elites in his book (Tilly, 2005a).

1.17 The theoretical answer to the role of ethnography in Tilly's intellectual agenda is found in his afterword to a journal issue edited by Javier Auyero (2006) on political ethnography. Talking about the work of Adam Ashforth (2005) in Witchcraft, Violence, and Democracy in South Africa, Tilly (2006a) comments,

Through first hand observation, personal intervention, and incessant interrogation of his acquaintances, Ashforth built up a powerful picture of coping, strife, and hope amid vicious violence. Ashforth's ethnographic involvement forced him to abandon many a preconceived category and explanation of struggle during and after Apartheid. Ashforth's ethnography yielded remarkable, even disturbing, results... His deep involvement in local life allowed him to reconstruct South African politics at the levels of persons, households, and small groups' (Tilly, 2006a:409-410)

1.18 And then talking more generally about the ethnography of everyday politics, what here is referred as 'political ethnography', Tilly comments enthusiastically,

To the extent that politics actually consists not of big structures and prescribed roles but of dynamic, contingent interaction among persons, households, and small groups, political ethnography provides privileged access to its processes, causes, and effects. It makes little difference in this regard whether we take politics in the extremely broad sense of all interactions involving the exercise of power or in the narrower, more manageable sense I prefer: interactions in which at least one government participates as actor, object, and/or influential third party. In either the broad or the narrow sense, political ethnography brings field workers into direct contact with political processes instead of filtering that knowledge through other people's testimony, written records, and artifacts of political interaction' (Tilly, 2006a:410)

1.19 This suggests just how far the Tilly of Big Structures... had gone, from privileging the historical record of contentious events, to incorporating the narratives of everyday living people so long as they also incorporate information and observations of interactions with others and thus avoid methodological individualism. Indeed, the later Tilly favored ethnographies over purely statistical or historical comparative work, because ethnography deals with processes.

1.20 If ethnography and lived experience provides superb data, for Tilly good narratives are the best way to present scientific findings. In many of his later books, Tilly illuminated contemporary daily behaviors. For example, why people see the need to give reasons and tell stories in our social life: Why? (Tilly, 2006c); why we assign blame and give credit to people around us: Credit and Blame (Tilly, 2008b, 2008c), and how researchers can reconcile the study of culture and the post-modern challenge with a research agenda that generates high quality and useful scientific social knowledge: The Oxford Handbook of Contextual Analysis (Goodin and Tilly, 2006).

1.21 In his last years, Tilly brought large social change, structural and institutional factors together with personal narratives and storytelling. His knowledge was encyclopedic and his technical knowledge and statistical sophistication was quite advanced, but as an author he would try to avoid purely scholastic or technical explanations over what he called 'superior stories' accompanied by contextualized stories, charts and diagrams: see Stories, Identities and Political Change (Tilly, 2002). Also, it should be noted that, after summarizing the contentious history of Switzerland, Tilly writes, even though he uses statistical information and Freedom House rankings, that 'crucial matching of arguments and evidence will come in the form of analytical narratives' (Tilly, 2007: 72). By this he means that he summarizes national and collective history not for its own sake, but to abstract common patterns, processes and mechanisms.

1.22 Tilly was an extremely prolific writer, publishing more than 51 single and co-authored books and well over seven hundred articles and working papers. Thus it was hard to keep up with his writings and easy to misrepresent his work given the size of his oeuvre, which I would claim one needs to consider as a whole and not as independent pieces. I remember him being disappointed when people equated him to any one of his books. He also used to complain that more people cited From Mobilization to Revolution (Tilly, 1978) than actually read it. In his last years, instead of waiting until a text reached 'perfection', that unattainable goal, or thinking that he had the ultimate word on a subject, Tilly was willing to publish fast in order to be proven wrong (or only partially right), and thus rendered perfectible. Indeed, why wait for someone else to fix his models? He often came back and improved his previous ideas. This is exemplified by the story he loved to tell about how his first book The Vendée (1964) was a refutation of his doctoral dissertation. One could argue that despite his sociability, Tilly was often in discussion mainly with himself. His work was a cumulative oeuvre where he tried to improve his previous statements, a common example being his change from a structural view to 'relational realism' (McAdam et al., 2001).

1.23 How can we explain his fecundity? Besides the long hours, his efficiency, his lucid mind, his love of writing, and the shadow of death, the reason for his productivity was the way he saw scientific endeavor. Tilly saw all scientific knowledge as temporary, and by this I do not mean that he was a postmodern writer or that the quality of his work is mediocre. He was never content with publishing and moving onto another issue. He saw the building of knowledge as a cumulative and collective process. Thus he constantly revisited, corrected, expanded and clarified his own work and that of his colleagues and students. He saw some of his short articles as teasers, sources of inspiration and ideas for others to follow up and develop in more detail. He also was quick to adopt good ideas from others around him and add them to the theoretical aggregate forming around his personal professional networks. 
1.24 Tilly studied the past in order to provide tools to understand the present and the future. He aimed to publish books and articles that changed the way we see history and do social science. He opposed methodological individualism and studies that locate responsibility in individual isolated consciousness and pushed for a relational understanding. In particular, he was interested in social interactions, including contentious ones, and the social networks they formed. When providing new concepts and mechanisms, he always kept the historical context in mind. He connected his interest in history with that in social movements, which, under the banner of contentious politics, compares the common mechanisms in civil wars, riots, revolutions, international wars, terrorism, protests, and many other events.

1.25 Despite his fame and intelligence, Tilly as a scholar was above all humble, accessible, without aristocratic pretensions; he was a true cosmopolitan, democratic and egalitarian in action. He was helpful and patient with his colleagues and students. He spent a lot of time helping us develop our ideas, reading all types of drafts and giving valuable suggestions to improve the scientific content of our texts. He constructed a social network, a community of scholars, to which he devoted years of work, love and dedication. The fact that this intellectual community withstands his death is a testimony to its strength and his success. Tilly was a great guide and model who has shaped generations of scholars.

\section{Notes}

${ }^{1}$ This article has its origins in a paper given at 'Contention, Change, and Explanation: A Conference in Honor of Charles Tilly' co-sponsored by the U.S. Social Science Research Council (SSRC) and Columbia University held in New York, 3-5 October, 2008. A longer version of that paper is available at: $<$ http://www.ssrc.org/hirschman/event/2008>.

Part of that text was adapted from a personal tribute to Charles Tilly that appeared in the SSRC website $<$ http://www.ssrc.org/essays/tilly/castaneda>.

Craig Calhoun and Andreas Koller provided comments on those essays. I want to thank the three anonymous reviewers for their useful suggestions, and Liz Stanley for her wise editorial help.

\section{References}

AMSELLE, J.-L. (2003) Affirmative Exclusion: Cultural Pluralism and the Rule of Custom in France, Ithaca, NY: Cornell University Press.

ASHFORTH, A. (2005) Witchcraft, Violence, and Democracy in South Africa, Chicago, IL: Chicago University Press.

AUYERO, J. (2003) Contentious Lives: Two Argentine Women, Two Protests, and the Quest for Recognition, Durham: NC: Duke University Press.

AUYERO, J. (2006) 'Introductory Note to Politics under the Microscope: Special Issue on Political Ethnography I', Qualitative Sociology, Vol. 29, No. 3 Special Issue: Political Ethnography I <http://www.springerlink.com/ content/xl0867087510146h/fulltext.pdf>. [doi:10.1007/s11133-006-9028-7]

BENDIX, R. (1978) Kings or People: Power and the Mandate to Rule, Berkeley, CA: University of California Press.

CALHOUN, C. and KOLLER, A. (2009) 'Charles Tilly's Interdisciplinary Influence', Swiss Political Science Review, Vol. 15, No. 2, pp. 333-39 <http://essays.ssrc.org/tilly/wp-content/ uploads/2009/07/spsr-specialsection-tilly.pdf>.

GAMBETTA, D. (1996) The Sicilian Mafia: The Business of Private Protection, Cambridge, MA: Harvard University Press.

GOODIN, R. E. and TILLY, C. (2006) The Oxford Handbook of Contextual Political Analysis, Oxford: Oxford University Press. [doi:10.1093/oxfordhb/9780199270439.001.0001]

LOVEMAN, M. (2005) 'The Modern State and the Primitive Accumulation of Symbolic Power', American Journal of Sociology, Vol. 110, No. 6, pp. 1651-83. [doi:10.1086/428688]

MCADAM, D., TARROW, S. and TILLY, C. (2001) 'Dynamics of Contention'. Cambridge, UK: Cambridge University Press.

MERRIMAN, J. (2008) 'I Went up to Amiens Today', Tributes to Charles Tilly.

SCOTT, J. C. (1998) Seeing Like a State: How Certain Schemes to Improve the Human Condition have Failed, New Haven, CT: Yale University Press.

TARROW, S. (1987) 'Big Structures and Contentious Events: Two of Charles Tilly's Recent Writings', Sociological Forum, Vol. 2, No. 1, pp. 191-204 <http://www.jstor.org/stable/684537>.

[doi:10.1007/BF01107904]

TILLY, C. (1964) The Vendée, Cambridge, MA: Harvard University Press.

TILLY, C. (1975) The Formation of National States in Western Europe, Princeton, NJ: Princeton University 
Press.

TILLY, C. (1978) From Mobilization to Revolution. , Reading, MA: : Addison-Wesley <http://hdl.handle.net/2027.42/50931>.

TILLY, C. (1981) As Sociology Meets History, New York: Academic Press.

TILLY, C. (1983) 'Speaking your Mind without Elections, Surveys, or Social Movements', The Public Opinion Quarterly, Vol. 47, No. 4, pp. 461-478. [doi:10.1086/268805]

TILLY, C. (1984) Big Structures, Large Processes, Huge Comparisons, New York: Russell Sage Foundation <http://deepblue.lib.umich.edu/ bitstream/2027.42/51064/1/295.pdf>.

TILLY, C. (1985) 'War Making and State Making as Organized Crime', in EVANS, P., RUESCHEMEYER, D. and SKOCPOL, T. (editors) Bringing the State Back In. Cambridge: Cambridge University Press <https://netfiles.uiuc.edu/rohloff/ www/war\%20making\%20and\%20state\%20making.pdf>.

[doi:10.1017/CBO9780511628283.008]

TILLY, C. (1992) Coercion, Capital, and European states, AD 990-1992, Cambridge, MA: Blackwell.

TILLY, C. (1998) Durable Inequality, Berkeley, CA: University of California Press.

TILLY, C. (2001) 'Predictions after September 11'. SSRC Online Forum

<http://essays.ssrc.org/sept11/essays/tilly.htm>.

TILLY, C. (2002) Stories, Identities, and Political Change, Lanham, Md.: Rowman \& Littlefield.

TILLY, C. (2005a) 'Review of Affirmative Exclusion: Cultural Pluralism and the Rule of Custom in France by Jean Loup Amselle', American Journal of Sociology, Vol. 110, No. 5, pp. 1553-1554. [doi:10.1086/431636]

TILLY, C. (2005b) Trust and Rule, Cambridge, UK: Cambridge University Press. [doi:10.1017/CBO9780511618185]

TILLY, C. (2006a) 'Afterword: Political Ethnography as Art and Science ', Qualitative Sociology, Vol. 29 , No. 3 Special Issue: Political Ethnography I, pp. 409-412 <http://www.springerlink.com/ content/w82q65u8r7527880/fulltext.pdf>.

TILLY, C. (2006b) 'Why and How History Matters', in GOODIN, R. E. and TILLY, C. (editors) Oxford Handbook of Contextual Political Analysis. Oxford, UK: Oxford University Press. [doi:10.1093/oxfordhb/9780199270439.003.0022]

TILLY, C. (2006c) Why?, Princeton: Princeton University Press.

TILLY, C. (2007a) Democracy, Cambridge: Cambridge University Press.

TILLY, C. (2007b) 'Mechanisms of the Middle Range', paper given at a conference in honor Robert K. Merton Conference hosted by the SSRC at Columbia University, 9-10 August 2007.

<http://essays.ssrc.org/tilly/wp-content/uploads/2008/06/ tilly-mechanisms-middle-range.pdf>.

TILLY, C. (2007c) 'Poverty and the Politics of Exclusion', in NARAYAN, D. and PETESCH, P. (editors) Moving Out of Poverty: Cross-Disciplinary Perspectives on Mobility. Palgrave Macmillan and the World Bank: New York, NY <http://siteresources.worldbank.org/

INTMOVOUTPOV/Resources/Tilly_Exclusion_021006.pdf>.

TILLY, C. (2008a) Contentious Performances, Cambridge: Cambridge University Press.

TILLY, C. (2008b) Credit and Blame, Princeton, NJ: Princeton University Press.

TILLY, C. (2008c) 'Memorials to Credit and Blame', The American Interest, Vol. May-June No. <http://www.ssrc.org/essays/tilly/creditblame>.

TILLY, C. (2009) 'Astonishing Switzerland', Swiss Political Science Review, Vol. 15, No. 2, pp. 321-31 <http://essays.ssrc.org/tilly/wp-content/uploads/2009/07/ spsr-special-section-tilly.pdf>.

TILLY, C. and TARROW, S. (2007) Contentious Politics, Boulder, CO: Paradigm Publishers.

ZELIZER, V. A. and TILLY, C. (2006) 'Relations and Categories', in MARKMAN, A. and ROSS, B. (editors) The Psychology of Learning and Motivation. San Diego, CA: Elsevier. 